
www.globaljournalseries.com; Info@globaljournalseries.com

\title{
RELATIONSHIP BETWEEN HEADTEACHERS' SUPERVISION OF TEACHING AND LEARNING MATERIALS UTILIZATION AND LEARNERS' PERFORMANCE IN ACTIVITY AREAS IN PUBLIC PRE-PRIMARY SCHOOLS IN NAROK COUNTY
}

KOSILEI JOHN KIPKOECH, DR. VIVILINE NGENO, AND DR. SYALLOW CAJERTANE MAKERO

(Received 7, May 2020; Revision Accepted 25, May 2020)

\begin{abstract}
The role of headteachers in the supervision of teaching and learning materials utilization even though widely studied has not been explored in regard to its influence on learners' performance in public preprimary Schools. The study's aim was to examine the relationship between headteachers' supervision of teaching and learning materials utilization on learners' performance in activity areas in public preprimary schools in Narok County. The study was informed by the Education Production Theory by Hanushek (1995) and Cognitive Load Theory by John Sweller (1988). Convergent Mixed Method design was used as it enables the researcher to handle both qualitative and quantitative data that were collected. The target population was 735 pre-primary schools, 735 Headteachers, 1470 pre-school teachers, 30 ECD Coordinators, and 6 Quality Assurance Standards Officers. The sample size comprised of 85 pre-primary schools, 85 head teachers, 85 pre-primary teachers from public preprimary schools, 6 Quality Assurance and Standards Officers and 9 ECD Coordinators. Purposive sampling was used in the selection of headteachers, while the sample for teachers, ECD Coordinators, and Quality Assurance Standards Officers was selected using simple random sampling technique. The researcher used questionnaires, Interview schedule, Center Performance Assessment Tool, and Center Observation Checklist as the main tools for collecting data. The researcher used qualitative and quantitative approaches to analyzing data. This assisted the researcher to summarize data for easy analysis. Regression Analysis was used to test the hypotheses. The results show that headteachers' supervision of teaching and learning materials utilization had a statistically significant influence on learners' performance in activity areas.
\end{abstract}

KEYWORDS: Headteachers' Supervision of Teaching and Learning Materials Utilization, Learners' Performance, Activity Areas, Pre-schools, Pre-Primary Schools

\section{INTRODUCTION}

Early Childhood Education (ECE) is an education given to children in pre-primary schools before beginning primary school (Oluwafemi, Nma, Osita \& Olugbenga 2014). The United Nations
Educational and Cultural Organization (UNESCO) (2010) describes early childhood as a period from birth to 8 years. This is the time that the brain is evolving dramatically. These 8 years of learning form the foundation for later learning (Landrum \& McDuffie, 2010). Hirst, Jewis, Sojo,

Kosilei John Kipkoech, Department of Education, Administration, Planning, Management,

Psychology \& Foundations, University of Kabianga

Viviline Ngeno, Department of Education, Administration, Planning, Management, Psychology \& Foundations, University of Kabianga

Syallow Cajertane Makero, Department of Environmental Science 
and Cavanagh (2011) argue that early childhood education for all children is very necessary and should therefore be made available to everyone. Pre-primary provides a solid basis for teaching and leads to the growth of knowledge, awareness, private information and trust, and a sense of social responsibility.

The United Nations Convention (1989) states that every child has the fundamental right to learn and develop his /her full potential through access to quality education regardless of age, gender, background or social background. High-quality education is partly effective management of education and learning materials. In public kindergartens, the management of teaching and learning materials is the responsibility of the Headteachers.

Teaching materials can refer to a number of teacher sources, however, the term generally refers to concrete examples such as worksheets or manipulations (learning material or games that allow learners to learn new knowledge, such as count blocks). Teaching and learning materials are essential for a successful teaching and learning process around the world. This is because these sources help the teacher effectively transfer the content to the toddler (Karaka, 2007). The link between teaching and learning materials management and learner performance has been cited in previous studies, some of which have existed for centuries. Montessori (1870) discovered that the use of teaching and learning materials influenced learning performance both positively and negatively.

Montessori (1998) pointed out that the use of concrete teaching and learning materials helps to develop five senses for children. This reduces the teacher's monotony of using only one material to improve learning. Karaka (2009) pointed out that concrete materials improve the understanding of basic concepts. Whatever the teacher intends, the most important thing is for the child to learn. The task of the teacher is to facilitate learning through education/teaching resources. Facilitation of learning in classroom by the teacher is subject to the effective management of teaching and learning resources. Everything the teacher prepares does not necessarily make sense if the child cannot learn. If the materials are displayed properly, they occupy the mind of the learners when the teacher is not in class. This will improve children's learning in the absence of the teacher.

School managers, therefore, have the responsibility of ensuring that teaching and learning materials are managed and utilized effectively, for this is important in the enhancement of learners' performance in all the activity areas. The use of teaching and learning materials gives the learner the opportunity to touch, smell or taste objects in the teaching and learning process (Dhakal, 2017). Knowledge and skill can be passed into pre-schoolers with different types of relevant teaching and learning materials. The use of teaching and learning materials becomes very crucial in improving the overall quality of the learning experiences of school level pre-schoolers. The school authority should supervise the utilization of local teaching and learning materials and to avail that are lacking in the school (Dhakal, 2017).

The question of use of teaching and learning materials for pre-primary schools arises because the materials are important in the teaching of any subject. Pre-school teachers can testify that teaching becomes easier with such materials (Mwonga \& Wanyama, 2012). Improper utilization of these teaching materials in an educational institution, the dream of reaching Vision 2030 and meeting the United Nations (UN) conventions on the rights of children becomes elusive. This research explored the influence of teaching and learning materials management by Headteachers on learner performance in terms of their supervisory functions in the utilization of teaching and learning materials. The study specifically, focuses on public pre-primary schools in Narok County. This is informed by the fact that the Narok County Education Office (2018), Department of Quality Assurance and Standards office reported that poor performance among preschoolers in public ECD centers was one of the pressing concerns that require urgent attention.

\section{STATEMENT OF THE PROBLEM}

In Kenya, learners' performance inactivity areas, in public pre-primary schools has remained unimpressive over the years. This is evidenced by the fact that the learners continue to perform below expectations in mathematics activities, language activities, Christian religious activities, environmental activities, psychomotor and creative activities. Research that relates to the management of teaching and learning materials with learning outcomes in pre-primary education in Kenya is scanty. While preschool headteachers are making efforts to ensure that the preschools have adequate teaching and learning materials, it remains unclear whether these materials are used effectively. The 
relationship of headteachers' supervision of materials utilization remains unexplored. Most studies focus on public elementary and middle schools (Orodho Waweru, Ndichu \& Nthinguri, 2013). Moreover, research on its effect on learners' performance in activity areas is limited in most parts of the country, Narok County included. Therefore, this study is critical, in that it unearthed the underlying factors that cause poor performance in Activity Areas in public preprimary schools in Narok County.

\section{OBJECTIVE:}

The objective of the study was to examine there lationship between headteachers' supervision of teaching and learning materials utilization and learners' performance in activity areas in public pre-primary schools in Narok County.

\section{Hypotheses}

$\mathrm{Ho}_{1}$ : There is no significant influence of headteachers' supervision of teaching and learning materials utilization on learner's performance in activity areas, in public preprimary schools in Narok County.

\section{LITERATURE REVIEW}

Early Childhood Education

Eddy (2016) describes Early Childhood Education (ECE); also known as pre-school education, as an area of educational theory that relates to the education of young children (formal and informal) from birth up to the age of about eight years. The education of children and babies, a subset of pre-school education, refers to the education of children from birth to the age of 8 years. It developed into a research area during the Enlightenment, especially in European countries with a high literacy rate.

According to the UNESCO (2019) Early childhood care and education (ECCE) is more than preparation for primary school. It aims at the holistic development of a child's social, emotional, cognitive and physical needs in order to build a solid and broad foundation for lifelong learning and wellbeing. In Kenya, Kamau (2018) pointed out that the ECDE serves the major critical responsibility of making children well prepared for their future education. There is minimal involvement by the Government of Kenya. One antecedent towards achievement of this aim is proper utilization of teaching and learning materials.

Utilization of Teaching and Materials and Learners Performance

In a study by Smart and Jagannathan (2018) it was found that teaching and materials were poorly used and some materials proved complex in their usage. This was attributed to factors such as use poorly trained or unqualified teachers and also poor supervision of the use of these materials. On the same note, from the context of developing countries, Glewwe, Hanushek, Humpage and Ravina (2011) noted supervised and motivated teachers worked hard. However, these studies did look at the link between supervision of Teaching and Materials utilization and learners' performance.

Mohammed (2016), in his study on the direct role of school headteachers for quality education and effective school management of primary schools in Nigeria, noted that effective teaching-learning process depends heavily on the use of relevant teaching and learning materials. The study also showed that teachers not only provided material for the effective completion of assigned tasks but also encouraged experimentation. School managers must ensure through supervision that teachers use the materials provided appropriately. This was achieved by offering teacher training courses by the ministry; however, the investigator did not investigate whether such an arrangement led to better performance in terms of learning activities. The purpose of this study will be to investigate whether the leadership and monitoring responsibilities of school headteachers in purchasing and usage of teaching and learning materials influence performance in pre-primary schools.

Makokha (2017) investigated the determinants of the use of improvised material in preschool education in science education in the Bungoma East Sub-county in the Bungoma County of Kenya. The study employed the correlational research design. Stratified sampling was used to select the pre-primary schools from the 58 headteachers. The study found out that in kindergartens, there were various improvised scientific teaching materials that were not sufficiently used. There was no significant correlation between teachers ' educational level and the use of improvised material in academic education. The difficulty was that while teaching and learning resources were available, they were not adequately used, suggesting head teachers' supervisory incompetence.

Nzambi (2012) examined the role of the headteachers in supervising the classroom as perceived by secondary school teachers in Kitui sub-county, Kitui County, Kenya. Descriptive design was used to carry out the study. The target population were all the schools in the 
larger Kitui District. The sample consisted of 120 respondents consisting of 60 Heads of Departments and 60 class teachers who were randomly selected from 6 high performing school and 6 low performing schools. The study found that principals in most schools did their best to lead the teachers and assist them with the use of teaching materials. In addition, principals encouraged teachers to participate in workshops, bring in new ideas and promote creativity, innovation and new skills. Effective guidance for teachers on the use of learning resources appears to have a positive impact on learner performance in the Kitui district, as conceptualized in this study. The focus of Nzambi, however, was on high schools and not on the pre-schools.

\section{Theoretical Framework}

The study employed the Cognitive Load Theory by John Sweller (1988).

\section{Cognitive Load Theory}

Cognitive Load Theory was developed by John Sweller in 1988 (Sweller, 1998). This theory states that the ability to learn or the mental capacity of a learner is limited to the learners' age and mental ability. The theory further states that learners may receive overwhelming information in terms of too much content or complex concepts and when the teaching and learning materials are not properly utilized, Consequently, this will result in over-load where learners are provided with more content than they can learn or handle. In other words, proper monitoring of allocation of teaching and learning resources enables learners perform better in their schoolwork. These are known as intrinsic load, extraneous load and germane load and, added together, make up the capacity of the working memory. This theory is relevant to the study in that the management of teaching and learning materials in pre-primary schools is argued to positively influence learners' performance in activity areas.

\section{RESEARCH METHODOLOGY}

This research design used was convergence mixed methods design. A convergent mixed methods design of mixing methods is a kind of structure in which qualitative and quantitative information is recorded separately and then combined (Creswell, 2014). This research design was chosen because the researcher collects and analyzes both qualitative and quantitative information over a comparable period of the research process, and then the two outcome agreements presented in a general interpretation. The research was conducted in Narok County. The County is located in the South Rift region of Kenya, formerly known as the Rift Valley province. Narok County is bordered by Nakuru County in the north, Kajiado in the east, Bomet in the west, and Tanzania in the south. Narok County has six educational sub-counties: Narok North, Narok East, Narok South, Narok West, Transmara West, and Transmara East. The researcher selected Narok County in that the performance trends in activity areas, as well as transition to standard one, have remained unimpressive over the past decade (Narok County Education Office, 2018).

The target population was 735 pre-schools, from which an accessible population of 1470 preschool teachers and 735 head teachers of public primary schools in Narok County were reached (See Table 1). The target population also included six quality assurance and standards officers of the sub-counties and 30 ECD coordinators.

Table 1: Target Population

\begin{tabular}{llll}
\hline Sub County & No. of Schools & Head Teachers & Teachers of Preschool \\
\hline Narok North & 176 & 176 & 352 \\
Narok East & 83 & 83 & 166 \\
Narok South & 148 & 148 & 296 \\
Narok West & 123 & 123 & 246 \\
Transmara West & 126 & 126 & 252 \\
Transmara East & 79 & 79 & 158 \\
Total & $\mathbf{7 3 5}$ & $\mathbf{7 3 5}$ & $\mathbf{1 4 7 0}$ \\
\hline
\end{tabular}

Source: Narok County Education Office (2018). 
All pre-schools in Narok County provide the sample framework for the study. The selection framework consisted of pre-primary schools, Headteachers and pre-primary teachers who are responsible for their respective pre-schools.

A stratified random selection was used in this study, whereby the strata comprised ofHead Teachers, Quality Assurance Officers and ECD Coordinators. The sample size of the pre-primary schools in the study has been calculated according to a scientific formula from Kothari (2004).

The sample size of this study was calculated using a scientific formula by (Kothari, 2004) as outlined below;

$\mathrm{n}=\quad \mathrm{Z}^{2} \mathrm{pqN}$

$\mathrm{e}^{2}(\mathrm{~N}-1)+\mathrm{Z}^{2} \mathrm{pq}$

Where:

$\mathrm{n}=$ the sample size for a finite population

$\mathrm{N}=$ size of population which is the number of preprimary school teachers and head teachers.

$p=$ population reliability (or frequency estimated for a sample of size $n$ ), where $p$ is 0.5 which is taken for all pre-primary school teachers and head teachers' population

$p+q=1$ e: margin of error considered is $10 \%$ for this study. $Z$ a /2: normal reduced variable at 0.05 level of significance $z$ is 1.96

According to the above formula, the sample size for all the pre-primary schools is:

$$
\begin{aligned}
n & =\frac{(1.96)^{2} \times 0.5 \times 0.5 \times 735}{(0.1)^{2}(735-1)+\left[(1.96)^{2} \times 0.5 \times 0.5\right]} \\
& =84.94103774 \\
& 85 \text { preprimary schools }
\end{aligned}
$$

Purposive sampling was used to sample 85 head teachers and 85 pre-school teachers (those in charge of every pre-school).

Census sampling technique was used when sampling Quality Assurance Officers from the six Sub-counties to be polled, each representing a Sub-county. Census technique is suitable in this case because it is economical and given the small size of this population (Farooq, 2013). This method had a high degree of accuracy and allows the researcher to represent the six geographical regions of the County.

The study used $30 \%$ of the population as the sample for ECD Coordinators, as informed by a recommendation by Gall, Gall and Borg (2003). Given that the population for these coordinators is 30 , it means $30 \%$ of (30) which is 9 ECD coordinator, when it is divided into the Six subcounties, it translates to 1.5, (that is 2 ECD
Coordinators per Sub County). Therefore, 10 ECD Coordinators were selected for the study, using a simple random sampling technique.

Primary data was collected via self-directed (oneto-one) semi-structured questionnaires and interview plans. Questionnaires were used to gather data from school Headteachers and preschool teachers while the survey schedule is used to gather data from quality assurance officers and ECD coordinators. An observation checklist was also kept at 85 pre-school schools to determine the availability and adequacy of teaching and learning materials. The interview schedules contained closed and open questions that were suitable for collecting qualitative data. They were used to collect data from the Quality Assurance Officers of Sub Counties and the ECD coordinators for all five research objectives.

The survey also collected secondary data from preschool teachers by reviewing learner progress records to verify performance. In the current Competency-Based Curriculum (CBC), Assessment Rubrics are used to check learning outcomes. A rubric is a teacher-generated tool that maps the specific learning outcomes that specify performance, level of success and mastery of the outcomes. Rubrics are meant to measure the product, process, and progress of learning $(\mathrm{KICD}, 2017)$. The Curriculum designs used parameters such as exceeding expectations, meeting expectations, approaching expectation and below expectations as levels of performance in pre-primary school.

In Bomet County, a pilot study was carried out at nine public pre-schools $(10 \%$ of the sample size of the 85 pre-schools). It ensured that selected pilot schools were not included in the sampled schools. The pilot study detected shortcomings in the questionnaires before the final data collection was carried out. Using test experiments, the researcher can determine whether respondents understand the instructions and questions in the research tools or not. Pilots, therefore, determined the reliability and validity of the research instrument.

The study conducted both Content validity and Construct validity. These types of validity of instruments were determined by consultation with university experts, from the University's Department of Education Planning and Management and the regulatory authorities, as this type of validity is not statistically measurable. The internal consistency of the instruments was tested by calculating Cronbach alpha reliability coefficients from the pilot studies using the 
benchmark with coefficient values greater than 0.7 . Reliability of the instruments was tested by computing Cronbach Alpha coefficients reliability using Test Retest approach from the pilot study data.Orodho (2008) states that a correlation coefficient of $>0.7$ is considered reliable to collect quality data for a study. Headteachers questionnaire scored a correlation coefficient of 0.712 , while that of the teachers recorded a score of 0.749 and thus, were considered reliable and adapted for the study.

The researcher requested for an introductory letter from the University of Kabianga to introduce the investigator to the respondents and Educational authorities. The permit and introductory letter were presented to the school Headteachers, who gave the researcher permission to carry out the research at preprimary schools.

The researcher applied for a research permit at National Commission for Science Technology and Innovation (NACOSTI). The permit was used to receive an introductory letter from the Director of Education in Narok County. The data collection tools were administered to respondents in person by the researcher.

The data in the questionnaires were cross checked to remove inconsistencies. The process of checking ensured that the answers were complete, accurate and suitable for further processing. The data was then encoded and finally analyzed electronically with Social Science Statistics Version 23 (SPSS).

Quantitative data was analyzed using both descriptive and inferential statistics. First, the descriptive statistics such as frequencies, averages, and percentages. Regression analyses were computed to determine the relationships between the variables in the study, as stated in the null hypotheses $\mathrm{H}_{01}-\mathrm{H}_{04}$. The regression analysis involved the computation of the ANOVA, t-tests, Beta value ( $\beta)$, as well as the $p$ values. The golden rule is to reject the null hypothesis when the $p$-value is less than 0.05 significant test $(p<0.05)$ and accept the null hypothesis when the $p$-value is greater than 0.05 ( $p>0.05)$.

The following regression model guided the study. LPAA $=\beta_{0}+\beta_{1}$ MATLM $+\varepsilon$

Where:

LPAA=Learners' Performance in Activity Areas MATLM = Monitoring Allocations of Teaching and Learning Materials

$\beta_{0}=$ regression Constant

$\beta_{1}$ : Regression coefficients for independent variables $\varepsilon=$ Error/Disturbance Term assumed to be normally distributed

The results for quantitative data were presented in the form of tables (tabular summaries) and charts (pie charts, graphs, and bar charts).

Qualitative data, which was collected from interview schedules and the ECD Centre teaching-learning materials observation checklist will be analyzed using Thematic Textual Analysis. This approach involved sorting and classification of related themes emerging from the responses. The classification was according to the study objectives. The results were presented in prose form (Narrations).

The research ensured that the permit to conduct the investigation was collected from the relevant authorities prior to the data collection. To ensure ethical behavior during the research process, the researcher sought and obtained written permission to conduct this research from the National Commission for Science, Technology, and Innovation (NACOSTI). The researcher then used the obtained permission to obtain approval from the Narok County Education Bureau to ensure that it is a legal exercise. Researcher also ensured that participants are treated with the highest respect and are aware that their participation is voluntary. Participants were fully informed about the purpose of the investigation and receive confidentiality and anonymity, as their identity and the information they provide remains confidential and anonymous. The participants were not exposed to any emotional stress because their participation is voluntary.

\section{RESULTS AND DISCUSSIONS \\ Respondents Response Rate}

The study was able to obtain a response from 81 headteachers and 85 teachers, thus translating to an average rate of $97.65 \%$. This was adequate to enable the researcher to come up with reliable conclusions and recommendations. Dommeyer, Baum, Chapman, and Hanna, (2002) reported that the acceptable response rate for on-paper surveys is $75 \%$, therefore the attained percentage was good and found acceptable to the researcher.

\section{Demographic Characteristics}

\section{Gender /Sex of the Respondents}

The results in Table 3 and Figure 1 show that $66.7 \%$ of the headteachers and $21.2 \%$ of the teachers were male respondents, while $33.3 \%$ of the headteachers and $78.8 \%$ of the teachers were female respondents. This implied in majority of the preschools, male respondents occupied headteachers positions, while majority of the 
preschool teachers were female. Likwop (2016) found that there were more male headteachers than female headteachers in Narok County. This result reveals a similar pattern, thus showing there are few women in school leadership in the county.

Table 2: Gender /Sex of Respondents

\begin{tabular}{|c|c|c|c|c|c|}
\hline & & \multicolumn{2}{|c|}{ Headteachers } & \multicolumn{2}{|c|}{ Teachers } \\
\hline & & $\mathbf{F}$ & $\%$ & $\mathbf{F}$ & $\%$ \\
\hline \multirow[t]{3}{*}{ Gender /sex of respondent } & Male & 54 & $66.7 \%$ & 18 & $21.2 \%$ \\
\hline & Female & 27 & $33.3 \%$ & 67 & $78.8 \%$ \\
\hline & Total & 81 & $100.0 \%$ & 85 & $100.0 \%$ \\
\hline
\end{tabular}

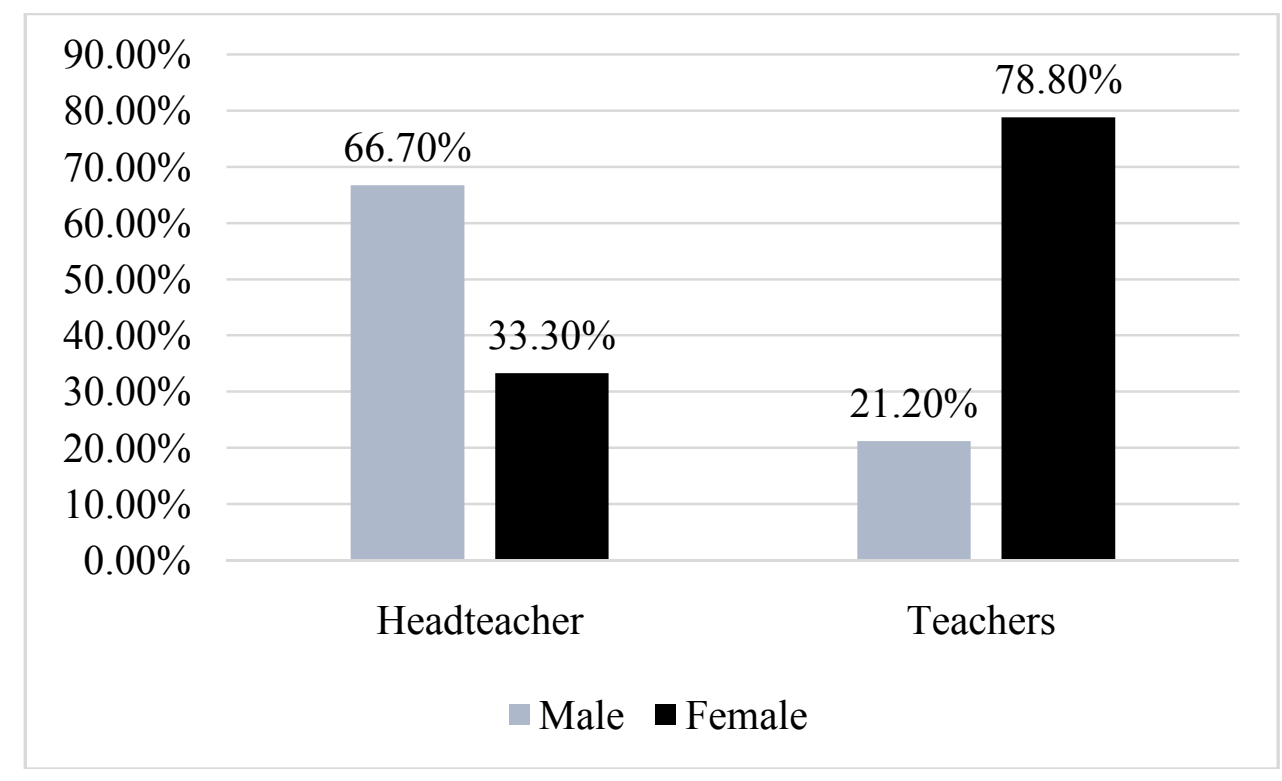

Figure 1: Gender/Sex of Respondents

\section{Age of Respondents}

The results in Table 4 show that, $39.5 \%$ of the headteachers and $11.8 \%$ of the teachers were in age bracket of 49 years and above. It is also shown that $49.4 \%$ of the headteachers and teachers were aged 37 to 48 years, whereas
$11.1 \%$ of the headteachers and $34.1 \%$ of the teachers were aged 28 to 37 years, while $4.7 \%$ of the teachers were aged 18 to 27 years. This implied that in both cases the respondents participating in the study were in the age bracket of 37 years or above

Table 3: Age of Respondents

\begin{tabular}{llllll}
\hline & \multicolumn{2}{l}{ Headteacher } & \multicolumn{2}{l}{ Teacher } \\
& & $\mathbf{F}$ & $\mathbf{\%}$ & $\mathbf{F}$ & $\mathbf{\%}$ \\
\hline Age of & $18-27$ years & 4 & $0.0 \%$ & 0 & $4.7 \%$ \\
Respondent & 9 & $11.1 \%$ & 29 & $34.1 \%$ \\
& 28-37 years & 36 & $49.4 \%$ & 46 & $49.4 \%$ \\
& 37-48 years & 32 & $39.5 \%$ & 10 & $11.8 \%$ \\
& 49 years and above & $\mathbf{8 1}$ & $\mathbf{1 0 0 . 0 \%}$ & $\mathbf{8 5}$ & $\mathbf{1 0 0 . 0 \%}$ \\
\hline
\end{tabular}




\section{Length of Service in the Current Station}

The results in Table 5 show that $71.6 \%$ of the headteachers and $84.7 \%$ of the teachers had been in their current workstation for a period above 3 years. The results also show that $22.2 \%$ of the headteachers and $10.6 \%$ of the teachers had been in their current workstation, while $6.2 \%$ of the headteachers and $4.7 \%$ of the teachers indicated a period below 1 year. The results suggest that majority of the teachers and headteachers had been in their current workstation for a period long enough to provide the information sought on the status of management of teaching and learning materials as well as on learners' performance in activity areas.

Table 4: Length of Service in the Current Station

\begin{tabular}{llllll}
\hline & & \multicolumn{2}{l}{ Headteachers } & \multicolumn{2}{l}{ Teachers } \\
& & $\mathrm{F}$ & $\%$ & $\mathrm{~F}$ & $\%$ \\
\hline How long have you & Below 1 year & 5 & $6.2 \%$ & 4 & $4.7 \%$ \\
been in the current & $1-3$ years & 18 & $22.2 \%$ & 9 & $10.6 \%$ \\
station? & Above 3 years & 58 & $71.6 \%$ & 72 & $84.7 \%$ \\
\hline
\end{tabular}

Descriptive Statistics for Headteachers' Supervision of Teaching and Learning Materials utilization on Learners' Performance The results in Table 6 with respect to the extent to which classroom supervisory visits did influence learners' performance in activity areas yielded the following mean scores. Headteachers responses recorded a mean score of 4.2500 , while that of the teachers recorded a mean sore of 4.0824. Both mean scores were above the 4.0 a value equivalent to large extent. The implication was that the headteachers and teachers in majority of the preprimary schools were of the opinion that classroom supervisory visits influenced learners' performance in activity areas largely.

The results in Table 6 with respect to the extent to which lesson observation in the use of teaching and learning materials did influence learners' performance in activity areas yielded the following mean scores. Headteachers responses recorded a mean score of 4.2875 , while that of the teachers recorded a mean sore of 4.0118. Both mean scores were above the 4.0 a value equivalent to large extent. The implication was that the headteachers and teachers in majority of the preprimary schools were of the opinion that lesson observation in the use of teaching and learning materials influenced learners' performance in activity areas largely.

The results in Table 6 with respect to the extent to which approval of lesson plans, schemes of work influenced learners' performance in activity areas yielded the following mean scores. Headteachers responses recorded a mean score of 4.0886 , while that of the teachers recorded a mean sore of 4.2588 . Both mean scores were above the 4.0 a value equivalent to large extent. The implication was that the headteachers and teachers in majority of the preprimary schools were of the opinion that headteachers' approval of lesson plans, schemes of work influenced learners' performance in activity areas largely.

The results in Table 6 with respect to the extent to which checking of learners progress reports influenced learners' performance in activity areas yielded the following mean scores. Headteachers responses recorded a mean score of 4.2500 , while that of the teachers recorded a mean sore of 4.0824 . Both mean scores were above the 4.0 a value equivalent to large extent. The implication was that the headteachers and teachers in majority of the preprimary schools were of the opinion that checking of learners' progress reports influenced learners' performance in activity areas largely.

The results in Table 6 with respect to the extent to which checking the suitability of teaching and learning resources used influenced learners' performance in activity areas yielded the following mean scores. Headteachers responses recorded a mean score of 4.1125 , while that of the teachers recorded a mean sore of 3.8235 . Both mean scores were above the 3.0 a value equivalent to moderate extent. The implication was that the headteachers and teachers in majority of the preprimary schools were of the opinion that checking the suitability of teaching and learning resources used influenced learners' performance in activity areas largely.

The results in Table 6 with respect to the extent to which checking the safety of teaching and learning resources used influenced learners' performance in activity areas yielded the 
following mean scores. Headteachers responses recorded a mean score of 3.9375 , while that of the teachers recorded a mean sore of 4.4471 . Both mean scores were above the 3.0 a value equivalent to moderate extent. The implication was that the headteachers and teachers in majority of the preprimary schools were of the opinion that checking the safety of teaching and learning resources used influenced learners' performance in activity areas largely. The results are similar to those in a study by Mwaniki (2015) who pointed out that learner performance was greatly a function of safe teaching and learning resources.

Table 5: Headteachers' Supervision of Teaching and Learning Materials utilization on Learners' Performance

\begin{tabular}{|c|c|c|c|c|c|c|}
\hline \multirow[t]{2}{*}{ Aspect } & \multicolumn{3}{|c|}{ Headteachers } & \multicolumn{3}{|c|}{ Teachers } \\
\hline & $\mathbf{N}$ & Mean & $\begin{array}{l}\text { Std. } \\
\text { Deviation }\end{array}$ & $\mathbf{N}$ & Mean & $\begin{array}{l}\text { Std. } \\
\text { Deviation }\end{array}$ \\
\hline Classroom supervisory visits & 80 & 4.2500 & 0.87872 & 85 & 4.0824 & 1.04894 \\
\hline $\begin{array}{l}\text { Lesson observation in the use of } \mathrm{T} / \mathrm{L} \\
\text { materials }\end{array}$ & 79 & 4.0886 & 0.87983 & 85 & 4.0118 & 1.04077 \\
\hline Approval of lesson plans, schemes of work & 80 & 4.2875 & 0.84485 & 85 & 4.2588 & 0.92778 \\
\hline Checking of Learners progress reports & 79 & 4.2532 & 0.91243 & 85 & 4.7765 & 5.91482 \\
\hline $\begin{array}{l}\text { Checking the suitability of teaching and } \\
\text { learning resources used }\end{array}$ & 80 & 4.1125 & 0.96776 & 85 & 3.8235 & 1.20689 \\
\hline $\begin{array}{l}\text { Checking the safety of teaching and } \\
\text { learning resources used }\end{array}$ & 80 & 3.9375 & 0.89079 & 85 & 4.4471 & 4.44679 \\
\hline Valid N (listwise) & 78 & & & 85 & & \\
\hline
\end{tabular}

\section{Descriptive Statistics for Learners} Performance in Activity Areas

The results in Table 7 show that learners' performance in activity areas recorded the following mean scores. Mathematics activities (headteachers $=2.7922$; teachers $=2.8916)$; Language activities (headteachers $=2.4615$; teachers $=2.6024$ ); Christian Religious Activities (headteachers $=2.9103$; teachers $=2.8916)$;
Environmental activities (headteachers $=2.9231$; teachers $=3.0723$ ); and Psychomotor \& Creative activities (headteachers $=2.9494$; teachers $=$ 2.9759). Overall, the means were below 3.0 neutral mean score. This implied that performance of learners' performance in activity areas was unimpressive. The lowest mean scores were in Language and Mathematics.

Table 6: Descriptive Statistics for Learners Performance in Activity Areas

\begin{tabular}{|c|c|c|c|c|c|c|}
\hline \multirow[t]{2}{*}{ Activity Area } & \multicolumn{3}{|c|}{ Headteachers } & \multicolumn{3}{|c|}{ Teachers } \\
\hline & $\mathbf{N}$ & Mean & Std. Deviation & $\mathbf{N}$ & Mean & Std. Deviation \\
\hline Mathematics activities & 77 & 2.7922 & 0.56980 & 83 & 2.8916 & 0.60510 \\
\hline Language activities & 78 & 2.4615 & 0.65846 & 83 & 2.6024 & 0.60364 \\
\hline Christian Religious Activities & 78 & 2.9103 & 0.64839 & 83 & 2.8916 & 0.62493 \\
\hline Environmental activities & 78 & 2.9231 & 0.57591 & 83 & 3.0723 & 0.57981 \\
\hline Psychomotor \& Creative activities & 79 & 2.9494 & 0.65826 & 83 & 2.9759 & 0.76471 \\
\hline Valid N (listwise) & 77 & & & 83 & & \\
\hline
\end{tabular}


Description of Learners' performance in Activity Areas by Quality Assurance Officers and ECD Coordinators'

The Quality Assurance Officers and ECD Coordinators in Narok County were asked to describe how they were able to assess learners' performance in activity areas in pre-schools in their area of administration. The responses were as follows: One of the QASO officers indicated: "I am able to monitor and evaluate performance through observation of learners and rating them using approved rating scales of: Exceeding Expectation, meeting expectation, approaching expectation and below expectation". This was the response provided by majority of the Quality Assurance Officers and ECD Coordinators in Narok County.

An ECD coordinator stated as follows: "As an administrative you go through teachers progress record made by the teacher of the learner and you are able to comprehend the learners' performance".
According to the most of the Quality Assurance Officers and ECD Coordinators' most of preschool learners in their administrative zones are at now approaching expectation in the following activity areas: Mathematics, Languages, Christian Religion, while environmental and psychomotor/creative activity most of them meet expectation.

A Centre performance tool was administered to the respondents and the results were as captured in Table 8. It was found that learners' performance levels reported the following mean scores, which were averages of number of leaners at each performance levels. The results were as follows: exceeding expectation (9.0714), meeting expectation (16.6706), approaching expectation (9.9529) and below expectation (5.3506). The results implied that most learners in the preschools were meeting expectation in activity areas. This was contrary to the results provided by the Quality Assurance Officers and ECD Coordinators.

Table 7: Learners' Performance as captured by the Centre Performance Assessment Tool

\begin{tabular}{llllll}
\hline & $\mathrm{N}$ & Minimum & Maximum & Mean & Std. Deviation \\
\hline Exceeding expectation & 70 & 1.00 & 50.00 & 9.0714 & 9.44906 \\
Meeting expectation & 85 & 2.00 & 60.00 & 16.6706 & 10.13409 \\
Approaching expectation & 85 & 2.00 & 35.00 & 9.9529 & 6.55000 \\
Below expectation & 77 & .00 & 28.00 & 5.3506 & 4.30045 \\
Valid N (listwise) & 63 & & & & \\
\hline
\end{tabular}

Correlations between Supervision in the use of Teaching and Learning Materials and Learners' Performance

The findings in Table 9 show that there was a positive Pearson correlation between headteachers' role of supervision in the use of teaching and learning materials and learners' performance in activity areas as follows: $(r=$ $0.167, p=0.031)$. This shows that there was an association between headteachers' role of supervision in the use of teaching and learning materials and learners' performance in activity areas. Given that, the $p$ value $(0.031)$, was less than the test significance level $(p<0.05)$, this relationship is statistically significant. These results are similar to those in a study by Karanja (2015) where it was observed that learning materials could be available at school, but how they are used determines learning performance at school. Moreover, the GoK (2005) report emphasized that school Heads must work with the education department to ensure that teachers are supervised to promote the effectiveness of the use of teaching and learning materials which will result in improved learning performance. 
Table 8: Correlations between Supervision in the use of Teaching and Learning Materials and Learners' Performance

\begin{tabular}{|c|c|c|c|}
\hline & & $\begin{array}{l}\text { Supervision in the use } \\
\text { of Teaching and } \\
\text { Learning Materials }\end{array}$ & $\begin{array}{l}\text { Learners' } \\
\text { Performance in } \\
\text { Activity Areas }\end{array}$ \\
\hline \multirow{2}{*}{$\begin{array}{l}\text { Supervision in the use } \\
\text { of Teaching and } \\
\text { Learning Materials }\end{array}$} & $\begin{array}{l}\text { Pearson } \\
\text { Correlation }\end{array}$ & 1 & $.167^{\circ}$ \\
\hline & $\begin{array}{l}\text { Sig. (2-tailed) } \\
N\end{array}$ & 166 & $\begin{array}{l}.031 \\
166\end{array}$ \\
\hline \multirow[t]{2}{*}{$\begin{array}{l}\text { Learners' Performance } \\
\text { in Activity Areas }\end{array}$} & $\begin{array}{l}\text { Pearson } \\
\text { Correlation }\end{array}$ & $.167^{\star}$ & 1 \\
\hline & $\begin{array}{l}\text { Sig. (2-tailed) } \\
\mathrm{N}\end{array}$ & $\begin{array}{l}.031 \\
166\end{array}$ & 166 \\
\hline
\end{tabular}

${ }^{*}$. Correlation is significant at the 0.05 level (2-tailed).

\section{Regression Analysis}

Multiple regression analysis was done to establish the relationship between the independent and dependent variables and the results are presented in this section. The variables under investigation included Supervision in the use of teaching and learning materials, availing of teaching and learning materials, maintenance of teaching and materials, monitoring of teaching and learning materials, and adequacy of teaching and learning materials (independent variables) and learners' performance (dependent variable).

\section{Model Summary}

The R Square value in the Model Summary table shows the amount of variance in the dependent variable that can be explained by the independent variables. The independent variables listed below Table 10 accounted for 2.8 percent of the variability in learners' performance in activity areas. The R-value (.167) is the multiple correlation coefficients between all the entered independent variables and the dependent variable. The Adjusted $\mathrm{R}$ Square adjusts for a bias as the number of variables increases. The Std. Error of the Estimate is a measure of the accuracy of the prediction.

Table 9: Model Summary

\begin{tabular}{lllll}
\hline Model & $\mathbf{R}$ & $\mathbf{R}$ Square & Adjusted R Square & Std. Error of the Estimate \\
\cline { 2 - 5 } 1 & $.167 a$ & .028 & .022 & .41938 \\
\hline
\end{tabular}

a. Predictors: (Constant), Supervision in the use of Teaching and Learning Materials

\section{Analysis of Variances (ANOVA)}

In the study, the predictors are significant when Sig. ( $p$ value) $p<0.05$. The findings in Table 11 show that $p$ value was 0.031 . Since the $p$ values are less than 0.05 (confidence level), we can conclude that the influence of headteachers' managerial competencies is significant. As $p<$ 0.05 our predictors are significantly better than would be expected by chance. The regression line predicted by headteachers' managerial competencies explains a significant amount of the variance in the level of effectiveness of school management. This is reported as follows: $F(1,164)=4.718 ; p<0.05$, and therefore can conclude that the regression is statistically significant. 
Table 10: Analysis of Variances (ANOVA)

\begin{tabular}{llllll}
\hline Model & Sum of Squares & df & Mean Square & F & Sig. \\
\hline 1 Regression & .830 & 1 & .830 & 4.718 & $.031 \mathrm{~b}$ \\
\hline Residual & 28.844 & 164 & .176 & & \\
\hline Total & 29.674 & 165 & & & \\
\hline
\end{tabular}

a. Dependent Variable: Learners' Performance in Activity Areas

b. Predictors: (Constant), Supervision in the use of Teaching and Learning Materials

\section{Beta Coefficients}

Beta Coefficients presented in Table 12 revealed the following. The regression model used was:

LPAA $=\beta_{0}+\beta_{1}$ SUTLM $+\varepsilon$

LPAA $=2.575+0.067+0.132$

From the findings, it emerges that the beta value for supervision in the use of teaching and learning materials was (Beta $=0.067 ; p=0.031$ ). The study hypothesis stated that " $\mathrm{Ho}_{1}$ : There is no significant influence of headteachers' supervision of teaching and learning materials utilization on learner's performance in activity areas, in public pre-primary schools in Narok County." Since the $p$ value associated with headteachers' supervision of teaching and learning materials utilization was 0.031 , which is less $0.05(p<0.05)$, the null hypothesis is rejected and therefore, the study holds that supervision of teaching and learning materials utilization by headteachers had a significant influence on learners' performance in activity areas, in public pre-primary schools in Narok County.

Table 11: Beta Coefficients

\begin{tabular}{lllllll}
\hline Model & & \multicolumn{2}{l}{$\begin{array}{l}\text { Unstandardized } \\
\text { Coefficients }\end{array}$} & $\begin{array}{l}\text { Standardized } \\
\text { Coefficients }\end{array}$ & t & Sig. \\
& B & Std. Error & Beta & & \\
\hline 1 & & & & & & \\
& (Constant) & 2.575 & .132 & & 19.565 & .000 \\
& $\begin{array}{l}\text { Headteachers' } \\
\text { supervision of teaching } \\
\begin{array}{l}\text { and learning materials } \\
\text { utilization }\end{array}\end{array}$ & .067 & .031 & .167 & 2.172 & .031 \\
& & & & & \\
\hline
\end{tabular}

a. Dependent Variable: Learners' Performance in Activity Areas

\section{CONCLUSIONS}

The study concludes that headteachers' supervision of teaching and learning materials utilization has a significant positive relationship with learners' performance in activity areas, in majority of the public pre-primary schools in Narok County. Classroom supervisory visits, lesson observation in the use of teaching and learning materials, headteachers' approval of lesson plans, schemes of work, checking the suitability of teaching and learning resources, and checking the safety of teaching and learning resources influenced learners' performance in activity areas largely. However, headteachers' supervision of teaching and learning materials was not effective in all the preschools.

\section{Recommendations}

The study's recommendations were as follows.

i. The school management should consider ensure that heads of department are keen on supervision of the use of teaching and learning materials. These materials need to be used appropriately and methodically so as to be able to register effectiveness in supporting learners' performance in the preschools. This can also be achieved through well thought delegated supervision.

ii. The school management should ensure that teachers are properly equipped with requisite skills for effective utilization of teaching and learning materials. The process can involve a critical and analysis of training needs as well as 
organizing update training on the use of the materials.

iii. To improve the use of improvised teaching materials in schools, teachers, headteachers, and other stakeholders need to work together and organize seminars, workshops, and capacity building gates to gain more power at the County and regional levels.

\section{REFERENCES}

Beyene, S., and Tezera, D., 2017.An assessment on educational materials management and utilization in Benishangul Gumuz Regional State Metekel Zonebullen primary school in focus. Journal of Scientific Research in Allied Sciences,3(3), 247-264

Cooper, D. and Schindler, P., 2013. Business Research Methods, 12th Edition 12th Edition. The McGraw- Hill /Irwin

Dhakal, K., 2017.Availability and utilization of instructional materials in teaching geography in secondary schools. The Third Pole: Journal of Geography, 17: 51-58.

Dommeyer, C. J., Baum, P., Chapman, K. S. and Hanna, R. W., 2002.Attitudes of business faculty towards two methods of collecting teaching evaluations: Paper vs. online. Assessment and Evaluation in Higher Education (27)5, pp. 455-462.

Eddy, M., 2016. "'The Child Writer: Graphic Literacy and the Scottish Educational System, 1700-1820'". History of Education. 46: 695-718.

Farooq, M. U., 2013. Improving prediction accuracy of hard-to-predict branches using data value correlation.

Gall, G. and Gall, J. P. Borg., 2003.Educational research: An introduction, 7.

Glewwe, P., Hanushek, E., Humpage, S. and Ravina, R., 2011.School Resources and Educational Outcomes in Developing Countries: a review of the literature from 1990 to 2010. National Bureau of Economic Research Working Paper 17554.

(www.nber.org/papers/w17554.pdf).
Forthcoming in P. Glewwe, (ed.),

Education Policy in Developing

Countries. University of Chicago Press.

Hanushek, E. A., 2008. Educational Production Functions. The New Palgrave

Hanushek, E., 1995. Interpreting recent research on schooling in developing countries. The World Bank Research Observer, 10(2), 27-246

Hirst, M., Jewis, W., Sojo, R and Cavanagh, S., 2011. Transition to Primary: A Review of the Literature. Retrieved From: Www.Kidsmatter.Edu.Au

Kamau2018.Early childhood education in Kenya $(E C D E)$ - Are the goals adequate? Available https://www.tuko.co.ke/269305-earlychildhood-education-kenya-ecde-aregoals-adequate.html

Karaka, K., 2007: Effective teaching in school. Oxford University Press, London.

Karanja, K., 2015. Management of T/L Resources in Primary Schools in Kandara Division, KandaraDistrict, Muranga County, Kenya.Kenyatta University.

KICD, 2017.Facilitator's Training Manual for Early Years Education Curriculum. Nairobi: $\mathrm{KICD}$

Kothari, R. C., 2004. Research Methodology: Methods and Techniques, 2nded. Delhi: New Age International

Labaree, R. V., 2009. Research Guides: Organizing Your Social Sciences Research Paper: Theoretical Framework

Landrum, T. J., and McDuffie, K. A., 2010. Learning styles in the age of differentiated instruction. Exceptionality, 18(1), 6-17.

Likwop, P. K., 2016. Influence of Headteachers' Instructional Supervision Practices On Pupils' Performance in Kenya Certificate of Primary Education in Mulot Division, Narok South, Kenya. University of Nairobi 
Mohammed, S., 2016.The Principals' Supervisory Roles for Quality Education and Effective School Administration of Basic Education Schools in Nigeria. Proceedings of ISER 18th International Conference, Dubai, UAE, ISBN: 978-9382702-45-0.

Makokha, E., 2017. Determinants of Pre-Primary School Teachers' Use of Improvised Materials in Science Instruction in Bungoma East Sub County, Bungoma County, Kenya. Kenyatta University.

Montessori, M., 1998: Discovery of child development. Oxford series London.

Montessori, M., 1870. The Montessori Method: The Origins of an Educational Innovation: Including an Abridged and Annotated Edition of Maria Montessori's The Montessori Method. Rowman and Littlefield Publishers, Inc. Oxford.

Mugenda, O. M., and Mugenda, A. G., 2003. Research methods. Nairobi: Acts Press

Muithungu, C. E., 2003: Teaching resources for young children. Longhorn Publishers Nairobi

Mwaniki, K. L., 2015. Influence of instructional resources of preschool children's performance in number work in Kairuri Zone, Embu County Kenya (Doctoral dissertation, Master's Thesis, University of Nairobi).

Narok County Education Office 2018.List of Public Pre-primary Schools. MoE.

Ngunjiri, J., 2012. Influence of Head Teachers' Instructional Supervision Strategies on Pupils Performance in Kenya Certificate of Primary Education in Public Primary Schools in Rumuruti Division, Kenya. University of Nairobi.

Nzambi, P., 2012. Role of the Headteacher in Instructional Supervision as Perceived by Teachers in Secondary Schools in Kitui District, Kitui County-Kenya. Kenyatta University
Okendu, J. N., 2012. The impact of school administrative structure and adequate supervision on the improvement of instructional processes. Academic Research International Journal 2(3): pp.497-500.

Okoth, U., 2014. Headteachers' leadership in providing instructional resources for environmental education in secondary schools in Siaya County, Kenya. USChina Education Review, 4(9), 634-647

Oluwafemi, O.L., Nma, A., Osita, O. and Olugbenga, O., 2014. Implementation of early childhood education: A case study in Nigeria. Universal Journal of Educational Research. 2(2): 119-125

Orodho J. Waweru, P. Ndichu, M. and Nthinguri, R., 2013. Basic Education in Kenya: Focus on Strategies Applied to Cope with School Based Challenges Inhibiting Effecting Effective Implementation of the Curriculum.

Orodho, J. A., 2008. Techniques of Writing Research Proposals and Reports in Education and Social Sciences. Bureau of Educational Research. Kenyatta University, Nairobi, Kenya: Kanezja HP Enterprises.

Sweller, J., 1988. Cognitive load during problem solving: Effects on learning, Cognitive Science, 12, 257-28.

UNESCO, 2019. Early Childhood Care and Education. Available at https://en.unesco.org/themes/earlychildhood-care-and-education

UNESCO, 2015.EFA. Global Monitoring Report 2000 - 2015. Achievements and Challenges.

UNESCO, 2010. Conference concept paper of The World Conference on Early Childhood Care and Education (ECCE): Building the Wealth of Nations. http://unesdoc.unesco.org/images/0018/0 01873/187376e.pdf (Accessed 3 June 2018.) 
United Nations. Office for Ocean Affairs, and the Law of the Sea. 1989. The Law of the sea: navigation on the high seas: legislative history of Part VII, Section I (Articles 87, 89, 90-94, 96-98) of the United

Nations Convention on the Law of the Sea (Vol. 18, No. 2). United Nations Publishers. Were, P., 201 and. Effects of T/L resources on preschool learners' transition to class one: a case study of

Rachuonyo South Sub County. Journal of Education and Practice.Vol.5, No.34, 2014.

Wiersma, W..1995. Research methods in education: An introduction (Sixth edition). Boston: Allyn and Bacon. 